\title{
Organic matter characterization and fate in the subarctic Norwegian fjords during late spring/summer period
}

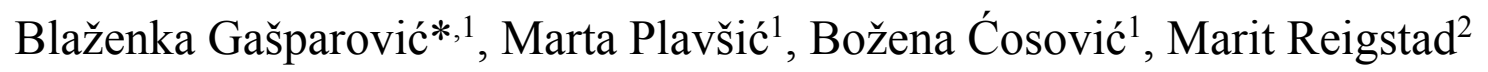 \\ ${ }^{1}$ Center for Marine and Environmental Research, Ruđer Bošković Institute, POB 180, HR- \\ 10002 Zagreb, Croatia; ${ }^{2}$ Norwegian College of Fishery Science, University of Troms $\varnothing$, N- \\ 9037 Tromsø, Norway
}

*Corresponding author (gaspar@irb.hr).

Tel.: +385-1-4561-148; fax: +385-1-4680-242

\begin{abstract}
The organic matter $(\mathrm{OM})$ pool has been studied in two subarctic north Norwegian fjords, Balsfjord and Ullsfjord, in July 2001 and June 2003. Besides general OM parameters such as dissolved organic carbon (DOC), particulate organic carbon and nitrogen (POC and PON), the distribution of specific compounds such as folic acid and surface active substances (SAS) was followed. The attained results are supported with the data of salinity and temperature, and chlorophyll $a(C h l a)$. This approach allowed to assess the fate of OM pool, and its distinct vertical, spatial, and seasonal variations. Fjord waters could be vertically divided in two layers: the upper mixed layer (UML), until $40 \mathrm{~m}$ depth, and the deep aphotic layer. Spatial variability between the two fjords is a consequence of different influences of shelf waters on the fjords. Significant enrichment of POC and PON concentrations ( 3 to 5 times), as well as those of particulate SAS and folic acid (up to 3.2 times) in the UML was recorded during the period of new production, in early June. Depletion of particulate OM in deep waters was ascribed to fast dissolution or remineralization in the UML or upper part of aphotic layer. OM in July 2001 was characterized with $15.9 \%$ higher DOC pool compared to June 2003, and had refractory properties, suggesting the fjords to be an important source of organic matter to continental shelf ecosystem. The DOC pool in these subarctic fjords represents the major component of OM pool. Fjords DOC concentrations are lower than those in previously
\end{abstract}


studied warmer seas (eg. The Adriatic Sea), whereas the concentrations of folic acid and SAS are comparable to those in the Adriatic Sea.

Keywords: organic matter (OM); folic acid; surfactant activity; subarctic fjords; Norway

\section{Introduction}

Marine organic matter $(\mathrm{OM})$ is one of the largest reservoirs of organic carbon on the Earth. Consequently, there is a great interest in the ocean`s organic carbon aiming to provide better understanding of the global carbon cycle (Williams \& Druffel, 1987). Shelf seas make up $<8 \%$ of the total oceanic surface area. However, continental shelves may play a disproportionately large role in oceanic carbon cycling since they represent conduits, linking terrestial sources of OM with the ocean and make the sites where approximately one-fifth to one-third of oceanic primary production occurs (Wollast, 1991; Schlesinger, 1997). OM dynamic in coastal waters, when compared to the open ocean, is more strongly influenced by biological, chemical, and physical processes on shorter time scales. The biogenic OM produced in the sea-surface is remineralized there or is exported to deeper waters/layers, depending on the physical and biological processes in the upper water column.

Generaly, dissolved organic carbon (DOC) accumulates during spring and summer in the surface waters of coastal seas like the Norwegian Sea (Børsheim \& Myklestad, 1997) and the Adriatic Sea (Vojvodić \& Ćosović, 1996). The annual accumulation of DOC and its subsequent decline in surface waters imply that DOC constitutes an important factor in a biological pump of carbon from the atmosphere to the seawater (Ducklow et al., 1995). The particulate organic carbon (POC), usually representing only $10 \%$ of DOC value (Thurman, 1985), could represent a significant part of OM in the productive months of spring and summer in the coastal seas (Gašparović \& Ćosović, 2003; Reigstad et al., 2000; Gilmartin \& Revelante, 1991; Gobler \& Sanudo-Wilhelmy, 2003). The POC and DOC are exported from the surface to deeper waters. The vertical flux of DOC out of the surface waters is mainly mediated by turbulent mixing and convection (Rudels \& Quadfasel, 1991) and by the dissolution of sinking particles (Cho \& Azam, 1988). 
It is estimated that $10-20 \%$ of DOM can be identified as specific compounds (Münster, 1993). The remaining DOM is a highly complex mixture that cannot be resolved into pure compounds. However, the determination of reactivity of organic substances in natural waters may provide better insight to the behaviour of organic carbon and improve our understanding of carbon circulation. This can be obtained through characterization of surface active substances (SAS). SAS as a part of OM mixture in the seas, represent a very reactive part. SAS accumulate in surface waters, primarily due to phytoplankton production (Žutić et al. 1981, Gašparović \& Ćosović 2001, 2003). The accumulation and decay rates of SAS are the consequence of the sum of production and consumption processes and of physical processes such as sinking and mixing. For the freshly produced SAS in the Northern Adriatic Sea the half-life time was found to be less than a few months while for heterodispersed SAS fraction it is in the order of weeks (Gašparović \& Ćosović, 2003).

Along with this largely uncharacterized pool of OM, specific well-defined organic molecules could play a significant role as indicators of the cycling of the trace constituents in coastal seawater and as such are markers of a certain biogeochemical processes. Folic acid (FA) could be regarded as an indicator for certain phytoplankton species as up to now a significant correlation was found between biomarker pigments for cyanobacteria and green algae (zeaxanthine and chlorophyll b, respectively) and the concentration of FA (Plavšić, Terzić, Ahel, \& van den Berg, 2002). FA is widespread in marine waters and could play a role as nutrient and at the same time could be released by microorganisms, representing as such an additional pool of available organics (Le Gall \& van den Berg, 1998; Plavšić, Lu, \& van den Berg, 1997). The spatial and seasonal distributions of FA depend on a sensitive balance between its production, consumption and UV-decomposition (Le Gall \& van den Berg, 1998; Plavšić, Terzić, Ahel, \& van den Berg, 2002; Plavšić, 2004), indicating that FA should be regarded as highly reactive compound in coastal waters.

The North Norwegian fjords are high-latitude fjords with regard to the light regime, however they are characterized by relatively high temperature and nonsignificant influence by glaciers. They are strongly influenced by the Atlantic Sea water with its relatively high temperature and salinity. They experience little fresh-water run-off from autumn to the middle May (Wassmann, Svensen, Keck, \& Reigstadt, 1996). Advection of water masses in and out of these fjords plays an important role for the ecology of this area (Wassmann, Svensen, Keck, \& Reigstadt, 1996). 
The amount of solar irradiation and daylenght periodicity create particular conditions for the seasonal progression of biological processes in the fjords. The spring bloom, from late March to late April, is followed by an additional increase in primary production in the MayJune period, probably due to fresh-water run-off. Primary production is usually rather low for the rest of the year (Eilertsen, Falk-Petersen \& Hopkins, 1981; Eilertsen \& Taasen, 1984; Riebesell et al., 1995).

Very little is known so far about the DOC pool and the composition of this pool in North Norwegian fjords or the high-latitude subarctic fjords in general. Investigations from the Barents Sea have shown that $18-55 \%$ of the primary production went to the dissolved organic pool (Vernet et al. 1998). DOC thus makes an important fraction of the carbon pool at high latitudes as well. Here, the results of a study on organic matter reservoirs combined with the determination of some specific compounds such as folic acid and surface active organic substances, in two North Norwegian fjords during the late spring/summer months in two years is presented. The results are supported with data on salinity and temperature and chlorophyll $a$ (Chl a). Such an approach allowed us to assess the fate of OM pool, its horizontal, vertical and seasonal variations. This can be of interest as a part of the study of global carbon biogeochemistry, especially since there is no any evidence for the behaviour of $\mathrm{OM}$ in Norwegian subarctic fjords.

\section{Materials and Methods}

\subsection{Study area}

The two fjords selected, Balsfjord and Ullsfjord, are characteristic for the northNorwegian coastal zone (Fig. 1). They differ from each other with respect to sill depth, width and exposure to the shelf area. Balsfjord (Station 1, N: 69 23.02`, E: $19^{\circ} 02.67^{`}$ and Station 2, $\left.\mathrm{N}: 69^{\circ} 34.32^{\prime}, \mathrm{E}: 18^{\circ} 54.62^{\circ}\right)$ is a semi-enclosed fjord with limited exchange with coastal waters due to the shallow sill $(30 \mathrm{~m})$ (Eilertsen, Falk-Petersen \& Hopkins, 1981). It has narrow configuration and $180 \mathrm{~m}$ maximum depth. It is characterized by moderate freshwater run-off, which is important for the waters circulation in summer. Wind driven circulation is 
there the most prominent (Svensen, 1995). Carbon sedimentation is seasonally dependent with increased vertical carbon flux after the spring bloom, which is followed by low summer sedimentation rates (Reigstad, pers. comm). Ullsfjord (Station 1, N: 69 47.185', E: $19^{\circ}$ 47.177') is wide and open, with 270 m maximum depth, exposed and separated from the shelf by a sill of $170 \mathrm{~m}$ depth. Ullsfjord is characterized by higher temperature and salinity compared to Balsfjord, due to the stronger influence of shelf waters. Freshwater run-off is moderate, similar to Balsfjord. The freshwater discharge to North Norwegian fjords is highly seasonal, however it is not prominent before the main snow melting takes place in late May and June.

\subsection{Sample collection}

Seawater samples were collected in the deep region and the entrance of Balsfjord (Station 1 and Station 2, respectively) and from Ullsfjord (Station 1) in late spring (2 - 6 June 2003), and early summer (2 - 8 July 2001). Samples are denoted as follows: B and U - Balsfjord and Ullsfjord; B1, B2, and $\mathrm{U} 1$ denoting station 1 or station 2 in the respective fjord, and last two numbers 01 and 03 denoting the years 2001 and 2003, respectively. All results were elaborated for the whole water profile, from the surface water, $0.5 \mathrm{~m}$, up to the bottom $(180$, 60 and $200 \mathrm{~m}$ max. depth for Stations 1 and 2 of Balsfjord, and Station 1 of Ullsfjord, respectively). Exception was sampling of Ullsfjord seawater in 2001 that was performed until $80 \mathrm{~m}$ depth. Samples were collected with 5-liter Niskin bottles and analyzed immediately after sampling in the land laboratory for electrochemical analyses. For the dissolved OM characterization, seawater samples were filtered $(-50 \mathrm{kPa})$ by using Whatman $\mathrm{GF} / \mathrm{F}$ glass fibre filters $(0.7 \mu \mathrm{m}$ pore size $)$ precombusted at the $450{ }^{\circ} \mathrm{C}$ for $5 \mathrm{~h}$. Sample bottles were cleaned first with chromic-sulphuric acid, and subsequently with 10\% nitric acid and Milli-Q water. All reagents were of AR quality obtained from Merck, unless indicated otherwise.

The temperature of seawater was measured with mercury-in-glas hand thermometer that has the scale graduated by one degree and the readings below one degree were estimates. Hence, the overall accuracy would be $\pm 0.5^{\circ} \mathrm{C}$. The salinity was measured with an Atago S10 (Japan) hand refractometer with accuracy within 1 salinity unit.

\subsection{Pigments determination}


Chlorophyll $a(\mathrm{Chl} a)$ was measured with a Turner Designs AU-10 fluorometer. Parallel samples $(3 \times 100 \mathrm{ml})$ were filtered through Whatman GF/F filters, extracted with $5 \mathrm{ml} \mathrm{100 \%}$ methanol at room temperature in the dark. The samples were afterward centrifuged and analyzed according to Holm-Hansen \& Riemann (1978) procedure. The fluorometer was calibrated with pure Chl a from SIGMA Chemical Co. The overall average standard deviation was $0.098 \mu \mathrm{g} \mathrm{l}^{-1}(n=62)$.

\subsection{DOC, POC and PON analyses}

The DOC concentrations were analyzed in duplicate by sensitive high temperature catalytic oxidation (HTCO) technique, proposed by Sugimura \& Suzuki (1988). A Model TOC-500 System (Shimadzu) with high-sensitive Pt catalyst and non-dispersive infrared (NDIR) detector for $\mathrm{CO}_{2}$ measurements was used. The POC and PON concentrations were determined in triplicate by filtering parallel samples $(3 \times 200 \mathrm{ml})$ through Whatman $\mathrm{GF} / \mathrm{F}$ filters preburned at the $450^{\circ}$ for $5 \mathrm{~h}$. The filters were stored frozen and exposed to $\mathrm{HCl}$ fume before analyzed to remove carbonates. The samples were analyzed with a Leeman Lab 440 elemental analyzer. The blanks for DOC, POC and PON were less than 7, 8 and $1 \%$, respectively, of the lowest detected concentration. The overall average standard deviations were $0.051 \mathrm{mg} \mathrm{l}^{-1}(n=102)$ for DOC, $0.016 \mathrm{mg} \mathrm{l}^{-1}(n=62)$ for POC and $0.0087 \mathrm{mg} \mathrm{l}^{-1}(n=$ 62) for PON, which corresponds to 3.8, 9.7 and 19.4\%, respectively, of mean values.

\subsection{Folic acid determination}

The FA has been determined by cathodic stripping voltammetry (CSV) (Le Gall and van den Berg 1993). A $\mu$-Autolab voltammeter (Eco Chemie, the Netherlands) connected to a Metrohm hanging mercury drop electrode (HMDE) (model VA 663) was used for the measurements of FA in seawater samples. The measurements in 2003 have been performed with Palm Sens hand-held instrument controlled by Pocket PC (Palm Instruments BV, the Netherlands) connected to the HMDE. Standard deviation of $6 \%(n=10)$ was estimated for $0.5 \mathrm{nmol}^{-1} \mathrm{FA}$ (using an adsorption time of $60 \mathrm{~s}$ ), from which the limit of detection of 0.09 nmol $1^{-1}$ is calculated from $3 \sigma$. The sensitivity is $0.8 \mathrm{nA}$ per $1 \mathrm{nmol}^{-1} \mathrm{FA}$. The CSV sensitivity was calibrated by the standard FA additions to the sample, buffered at $\mathrm{pH} 8.3$ with borate buffer $\left(1 \mathrm{~mol} \mathrm{l}^{-1}\right.$ boric acid, $\left.0.4 \mathrm{~mol} \mathrm{l}^{-1} \mathrm{NaOH}\right)$ to a final concentration of $0.01 \mathrm{~mol} \mathrm{l}^{-1}$ 
borate. Stock FA solutions were diluted daily from a $0.02 \mathrm{~mol}^{-1}$ stock solution, which was prepared weekly in $0.01 \mathrm{~mol} \mathrm{l}^{-1} \mathrm{NaOH}$ and kept in the dark at $4{ }^{0} \mathrm{C}$.

\subsection{Characterization of SAS by using o-nitrophenol as an electrochemical probe}

Surface-active substances (SAS) were determined by phase-sensitive alternating current (a.c.) voltammetry using in-phase measurements with $o$-nitrophenol as an electrochemical probe. All experimental details are given elsewhere (Gašparović \& Ćosović, 1994; 1995; 2003). Each seawater sample was measured four times. The reproducibility of electrochemical measurements was 8-10\%.

Characterization of SAS by using o-nitrophenol as an electrochemical probe is based on the fact that the electrochemical characteristics of o-nitrophenol (peak potential, height and shape, and prepeak height) change in significantly different ways, depending on the properties of adsorbed organic substances (hydrophobicity, acidity). The shift of the o-nitrophenol peak potential depends on OM hydrophobicity (Gašparović \& Ćosović, 1994) and represents OM surfactant activity. The surfactant activity (SA) of the complex mixture of organic matter in a natural seawater sample is expressed as the equivalent concentration of the nonionic surfactant Triton-X-100 (T-X-100), which produces the same effect on the o-nitrophenol peak potential shift $(\Delta \mathrm{E})$ as natural organic substances in the sample. The calibration curve for the dependence of the $o$-nitrophenol peak potential shift on the T-X-100 concentration was presented in a previous paper (Gašparović \& Ćosović, 2001). The lower limit of detection expressed as T-X-100 concentration is $0.02 \mathrm{mg} \mathrm{l}^{-1}$. The results were elaborated both for nonfiltered and filtered samples. Nonfiltered sample consists of the dissolved and of the particulate surface-active organic matter. Filtered sample represents the dissolved fraction. The difference between nonfiltered and filtered sample represents the contribution of particulate fraction to the surfactant activity (Gašparović \& Ćosović, 2003).

The change in prepeak height is indicator of OM acidity (Gašparović \& Ćosović 1995; Gašparović, Ćosović \& Vojvodić, 1998). To better characterize the complex mixture of organic substances in seawater the relative acidity of organic matter in seawater sample was determined. The increase in prepeak height $\left(\left(\mathrm{I}_{a} / \mathrm{I}_{\mathrm{a} 0}-1\right)\right.$ is normalized to the surfactant activity (expressed as equiv. concentration of $\mathrm{T}-\mathrm{X}-100$ ). This value is called relative acidity and represents an arbitrary unit of acidity per surfactant activity $\left(1 \mathrm{mg}^{-1}\right)$ (Gašparović \& Ćosović, 2003). It was shown that the highest contributions to the acidity or the highest relative acidity, 
in a broad surfactant activity range and for the concentrations which might be found in seawater, have polyelectrolytic humic $\left(\sim 251 \mathrm{mg}^{-1}\right)$ and fulvic $\left(\sim 201 \mathrm{mg}^{-1}\right)$ type substances. The relative acidity decreases in the cases of the models for freshly produced biogenic substances in the following order: albumin, model for proteins $\left(\sim 151 \mathrm{mg}^{-1}\right)$; xanthan, model for acidic polysaccharide $\left(\sim 121 \mathrm{mg}^{-1}\right)$; and linoleic acid, model for lipid materials $(\sim 2.51$ $\mathrm{mg}^{-1}$ ). The relative acidity of the neutral polysaccharide dextran T- 500 is zero, as expected for a non-acidic substance. All experimental details were given elsewhere (Gašparović \& Ćosović, 2001; 2003).

\section{Results}

\section{1. Hydrographical conditions and phytoplankton standing crop}

The salinity and temperature distributions throughout the water column at the investigated stations in two years are presented in Fig. 2a. Decreased salinity, as indirect indicator of the input of nutrients to the region from snow melting, has been observed for surface waters in both years. In July 2001, the dilution was mostly spread until $10 \mathrm{~m}$ depth, whereas in June 2003, a period of main snow melting, decreased salinity has been recorded until $50 \mathrm{~m}$ depth. Balsfjord exhibited lower salinity throughout the water column in comparison with Ullsfjord, with pronounced lower salinity in the surface upper $5 \mathrm{~m}$ depth.

Seawater temperature for both fjords and in both years varied between $3.5{ }^{\circ} \mathrm{C}$ in deep waters and $12{ }^{\circ} \mathrm{C}$ at the surface layer. Surface layer of Balsfjord had higher temperature compared to that of Ullsfjord, in both years. In deeper layer situation was inverse, except for Station B2 which is located at the Balsfjord entrance. The observed hydrographic differences between the two fjords are the consequence of stronger influence of shelf waters and vertical mixing on Ullsfjord than on Balsfjord hydrography.

Determination of Chl $a$ as a main photosynthetic pigment is the most common method for estimating the crop of primary producers in the marine environment. The phytoplankton dynamics in 2003, as reflected by Chl a distribution, is presented in Fig. 2b. As observed from Chl a concentration levels, the Northern Norwegian fjord waters might be divided in two 
parts: the upper mixed layer (UML), approximately until $40 \mathrm{~m}$ depth, and the deeper, aphotic layer, from $50 \mathrm{~m}$ depth to bottom. UML is created by the stratification and the algae are transported within this layer by the wind and tidally induced mixing. Chl a concentrations were rather variable in surface waters, exhibiting the highest values at depths from 5 to $20 \mathrm{~m}$, depending on the station. The Station B103, which was under higher influence of freshwaters, exhibited Chl $a$ concentrations in the UML between 0.95 and $4.03 \mu \mathrm{g} \mathrm{1^{-1 }}$, that was almost two times higher compared to the Stations B203 and U103, which were $0.84-1.78$ and $0.69-2.01$ $\mu \mathrm{g} \mathrm{l}^{-1}$, respectively. Deeper waters were characterized by slowly decreasing and low Chl $a$ pigment concentrations, between $0.02-0.32 \mu \mathrm{g}^{-1}$, with the average value of $0.113 \mu \mathrm{g}^{-1}$.

\subsection{DOC, $P O C$ and $P O N$}

DOC pool was different for the two years (Table 1). Higher DOC values were found in July 2001, in the entire depth profile, than in June 2003. DOC concentrations varied more in the UML, and less in the deeper aphotic layer. During 2001 and 2003 average DOC concentrations in the UML were $1.48 \mathrm{mg} \mathrm{C}^{-1}$ and $1.29 \mathrm{mg} \mathrm{C}^{-1}$, respectively. The average DOC concentrations below $40 \mathrm{~m}$ depth were $1.45 \mathrm{mg} \mathrm{C}^{-1}$ in 2001 and $1.14 \mathrm{mg} \mathrm{C}^{-1}$ in 2003. The DOC value at $180 \mathrm{~m}$ depth at the Station B1 was not included in the calculation of average value due to the completely different characteristics from the upper layer. The two fjords exhibited difference in DOC content for both years, (Balsfjord exhibited higher DOC concentrations than Ullsfjord). The Station B1, which was under higher influence of freshwaters, exhibited DOC concentrations in the UML between 1.35 and $1.78 \mathrm{mg} \mathrm{l}^{-1}$, and 1.09 to $1.50 \mathrm{mg} \mathrm{l}^{-1}$ in 2001 and 2003, respectively. The Station U1 exhibited UML DOC concentrations between 1.21 and $1.71 \mathrm{mg} \mathrm{l}^{-1}$, and 1.18 to $1.43 \mathrm{mg} \mathrm{l}^{-1}$ in 2001 and 2003, respectively. Average DOC concentrations were $1.52 \mathrm{mg} \mathrm{Cl}^{-1}$ for B101; $1.24 \mathrm{mg} \mathrm{Cl}^{-1}$ for B103; $1.24 \mathrm{mg} \mathrm{Cl}^{-1}$ for B203; $1.35 \mathrm{mg} \mathrm{C}^{-1}$ for $\mathrm{U} 101$ and $1.18 \mathrm{mg} \mathrm{C}^{-1}$ for $\mathrm{U} 103$.

Depth distributions of POC and PON are presented in Table 1. Average concentrations of POC and PON, for all investigated samples, in the upper $40 \mathrm{~m}$ depth layer, were 0.355 and $0.053 \mathrm{mg} \mathrm{l}^{-1}$, respectively, while in deeper layers POC and PON concentrations were much lower, i.e. average values were 0.100 and $0.013 \mathrm{mg} \mathrm{l}^{-1}$, respectively.

In Table 1 there are also given the values of POC contribution to the total organic carbon (TOC) in percent, as well as POC/PON ratios. POC contributed to the TOC with higher percent in the UML, between 12 and $34 \%$ with $21 \%$ in average. In deeper layers POC 
contribution to the TOC showed a decreasing tendency towards the bottom. Average POC percent in deeper layers was $8.1 \%$. General characteristic of POC/PON ratio in fjord waters was higher $\mathrm{C} / \mathrm{N}$ ratio in deep waters. The highest $\mathrm{C} / \mathrm{N}$ ratio was determined as 13.5 at 100

$\mathrm{m}$ depth for B103.

\subsection{Folic acid}

The concentrations of FA varied over a wide range in both fjords (Fig. 3). In July 2001 the FA concentrations in the UML were mostly less than $1 \mathrm{nmol} \mathrm{l}^{-1}$, with average concentration of $0.6 \mathrm{nmol} \mathrm{l}^{-1}$. In deeper layers average FA concentration was $3.4 \mathrm{nmol} \mathrm{l}^{-1}$. The highest value was found at $60 \mathrm{~m}$ depth for B101 $\left(9.2 \mathrm{nmol} \mathrm{l}^{-1}\right)$, and at $50 \mathrm{~m}$ depth for U101 $\left(5.2 \mathrm{nmol} \mathrm{l}^{-1}\right)$.

In June 2003 much higher FA values were found in the UML, up to $31 \mathrm{nmol}^{-1}$ at $30 \mathrm{~m}$ depth for U103; $22 \mathrm{nmol} \mathrm{l}^{-1}$ at $5 \mathrm{~m}$ depth for B203 and $15.4 \mathrm{nmol} \mathrm{l}^{-1}$ at $30 \mathrm{~m}$ depth for B103. Average FA concentration in the UML in 2003 was $9.63 \mathrm{nmol}^{-1}$. Relatively high concentration of FA was found in deep waters in 2003, with mean value of $5.9 \mathrm{nmol} \mathrm{l}^{-1}$.

\subsection{Surface-active organic substances}

Surfactant activity (SA) distributions (Fig. 4a) showed marked differences between the two layers for both fjords and in both years. The UML of lower salinity, brackish waters, exhibited markedly higher concentrations and remarkable variations of the SA. Deeper, more saline, waters were characterized by slowly decreasing SA, with average value of $0.055 \mathrm{mg} \mathrm{l}^{-1}$ in equiv. of T-X-100.

Higher SA values in the UML were recorded in June 2003 in comparison to July 2001. SA values at the Station B101 were in the range between 0.078 and $0.112 \mathrm{mg} \mathrm{l}^{-1}$ equiv. to T$\mathrm{X}-100$. The same Station, B103, two years later exhibited the values between 0.065 and 0.155 $\mathrm{mg}^{-1}$ equiv. to T-X-100. The highest SA values were detected at the $5 \mathrm{~m}$ depth. SA values obtained for entire depth profile, until the $60 \mathrm{~m}$ depth, at Station B203 were in the range from $0.07-0.123 \mathrm{mg} \mathrm{l}^{-1}$ equiv. to T-X-100. The values of SA obtained for Ullsfjord, Station U101 and $\mathrm{U} 103$ were in the range of $0.067-0.090 \mathrm{mg} \mathrm{l}^{-1}$ and $0.087-0.126 \mathrm{mg} \mathrm{l}^{-1}$ equiv. to T-X100, respectively. Maximum values for Station U103 and U101 were obtained at $5 \mathrm{~m}$ and at $10 \mathrm{~m}$ depths. 
Relative acidity of OM mixture in the fjord waters, extracted from the electrochemical measurements, is considered to find the dominant type of surface-active OM present in fjord waters. From model experiments it is known that biogenic SAS contribute less to the relative acidity $\left(0\right.$ to $\left.\sim 15 \mathrm{l} \mathrm{mg}^{-1}\right)$ than recalcitrant substances such as fulvic and humic acids $(\sim 20-25$ $1 \mathrm{mg}^{-1}$ ). Mean relative acidity of SAS (Fig. 4b), was $13.641 \mathrm{mg}^{-1}$ for the UML samples taken in July 2001 and $12.11 \mathrm{mg}^{-1}$ for those collected in June 2003. Mean relative SAS acidity for deeper layers was $18.72 \mathrm{l} \mathrm{mg}^{-1}$ in July 2001 and $14.351 \mathrm{mg}^{-1}$ in June 2003, respectively.

The contribution of the particulate fraction to the total surfactant activity is presented in Fig. 4c. Particulate fraction contribution was up to the $45 \%$ in the UML, with maximum values observed for depth between $10 \mathrm{~m}$ and $20 \mathrm{~m}$. In deeper waters SA originated mostly from the dissolved fraction. Heterodispersed surface-active organic substances, composed mostly of proteinaceous OM (Gašparović and Ćosović 2003), were found in fjord waters mainly in June 2003 in upper $30 \mathrm{~m}$ layer. The results of heterodispersed fraction are not presented since they are not quantitative due to irreproducible effects on the $\mathrm{Hg}$ electrode.

\subsection{Enrichments}

In general, vertical and horizontal dynamics of $\mathrm{OM}$ in North Norwegian fjords can be evaluated from the enrichment factors (EF). Vertical dynamic is indicated by the EF between the UML and the deeper waters (EF (UML/deep)). EF (UML/deep) are elaborated separately for the all stations together for 2001 and 2003 to indicate seasonal/interannual variability, and also separately for B1, B2 and U1 for both years. EF between the UMLs of stations B1 and U1 $(\mathrm{EF}(\mathrm{B} 1 / \mathrm{U} 1))$ indicate horizontal variations. The EF are calculated from the average values between UML and deep layer and between UMLs of B1 and U1. Results of EF are summarized in Table 2. It is important to emphasize that Station U101 was sampled only to the depth of $80 \mathrm{~m}$, and that Station B2 is shallow (60 m max. depth). These shallow waters are highly influenced by the UML. Therefore EF for Stations B203 and U101 were influenced accordingly by higher or lower values of certain parameter. This fact also slightly influence calculated EF for the entire region. 


\section{Discussion}

In this paper substantial data on organic matter distribution and its reactivity for two subarctic Norwegian fjords are presented for the first time, to our knowledge. Apart from the general organic matter parameters such as DOC, POC and PON, which provide insight into $\mathrm{OM}$ pool, specific substances such as folic acid and surface active substances were determined, which from other point of view gave insight into the new OM production and reactivity. The results are elaborated for the samples taken in two months, July 2001 and June 2003, respectively.

During the investigation period in late spring/early summer, freshwater run-off established a surface layer with warmer and less saline water in both fjords, being more pronounced at Station B1. In coastal and shelf areas additional nutrient inputs by freshwaters have a strong impact on phytoplankton dynamics, resulting often in enhanced standing stock of phytobiomass (Denant, Saliot, \& Mantoura, 1991). Hydrological situation in the fjords has been reflected in Chl a distribution and concentrations, as determined in 2003. Phytoplankton distribution, detected by Chl a concentrations, furthermore influenced OM concentrations and its characteristics in these fjords.

DOC pool represented a major component of organic carbon pool in the investigated subarctic fjords. DOC concentrations were in the range from 0.96 to $1.78 \mathrm{mg} \mathrm{l}^{-1}$ (Table 1). These concentrations are comparable to those reported for the Norwegian Sea, $53-149 \mu \mathrm{mol}$ C (0.64 - $\left.1.79 \mathrm{mg}^{-1}\right)$ (Børsheim \& Myklestad, 1997). DOC contribution to the TOC in June 2003 was $65-87 \%$ in the UML, and $83-94 \%$ in the deep fjord waters, respectively. Dissolved organic matter concentrations were more variable in the UML than in deep waters. Relatively low enrichments between the UML and deeper layers in 2001 and 2003 were found, 1.02 and 1.13, respectively (Table 2). This may suggest that substantial portion of DOC pool may have survived decomposition there and would serve thus as a net export of recently fixed carbon from this system. Furthermore this could be an indication of limited bacterial activity on dissolved organic matter pool, in this region, as bacterial DOC uptake is controlled by temperature (Pomeroy \& Deibel, 1986; Middelboe \& Lundsgaard 2003). It was demonstrated that in the high northern latitude Nordic Seas physical processes play a determining role for the distribution of DOC that counteract microbial mineralization of DOM (Amon, Budéus \& Meon, 2003). Amon and Benner (2003) have found that $2.2 \%$ of the 
DOC was of labile nature in the investigated region of Arctic Mediterranean Sea that includes Norwegian Sea. This suggested that DOM is less bioavailable and that microbial loop is there less active than of surrounding oceans. The accumulation of DOC in the UML of 1.2 times is reported for the Norwegian Sea, $66^{\circ} \mathrm{N}, 2^{\circ} \mathrm{E}$ (Børsheim \& Myklestad, 1997).

Detected DOC values in the entire region were approx. $16 \%$ higher in July 2001 compared to June 2003. This difference probably reflects seasonal variation in DOC pool between early summer and late spring rather than its interannual variability. Increased DOC pool in July might be explained by the dissolution and/or transformation of earlier developed POC pool to the DOC pool by heterotrophic bacteria that increased in abundance after phytoplankton bloom in Norwegian coastal waters (Larsen et al., 2004). DOC measurements in the same fjords in April 1997, revealed the concentrations from 75-100 $\mu \mathrm{mol} \mathrm{l}^{-1}$ (A. Miller, personal comm.), supporting that the increased DOC concentrations observed in July may result from the seasonal phytoplankton blooms in spring and early summer. Furthermore, long-term investigations in the Adriatic Sea showed maximum DOC content in post bloom periods in middle summer, that follows SAS maximum with one or two months delay (V. Vojvodić, \& B. Ćosović, personal comm.).

Vertical distributions of POC and PON show a substantial difference between the UML and deeper waters and, in addition, there was a substantial difference between the two fjords and between the stations. The highest POC as well as PON concentrations were found in the UML, enrichments were around 4 times for both parameters (Table 2). Their depletion in fjords deep waters indicates fast dissolution, grazing, and/or remineralization of particulate $\mathrm{OM}$ in the UML and upper aphotic zone. Destruction and mineralization of sedimenting matter is of significance below the UML, as well as resuspension that is of importance in the lower water column (Wassmann, Svensen, Keck, \& Reigstadt 1996). Furthermore, the transport of particulate organic matter to the depth depends not only on bottom-up regulation as determined by physical forcing, but also on the structure and function of the prevailing planktonic food web (Wassmann, 1998). North Norwegian seawaters are characterized by the strong decrease in carbon sedimentation just below the UML (Wassmann, Olli, Wexels Riser, \& Svensen, 2003).

Overall POC and PON concentrations correlated well with Chl $a(R=0.912$ and $R=$ 0.922 , respectively, $P<0.0001)$. These results suggest dominant contribution of new phytoplankton-originated organic carbon to POC and PON pools. Consequently, POC contributed highly to TOC in the UML, up to $34 \%$, and less in the aphotic layer. The increase 
of POC during the bloom has been already noticed by Gobler \& Sanudo-Wilhelmy (2003) in late May/early June in Shelter Island, NY.

General characteristic of POC/PON ratio (Table 1) in fjord waters was increasing C:N ratio towards the bottom, compared to the Redfield ratio. Significantly increased C:N ratio, more than 11, was found at $80 \mathrm{~m}$ depth in Balsfjord, whereas in Ullsfjord such ratio was found at $180 \mathrm{~m}$ depth. This result implies POM fractionation during remineralization in fjord waters (Shaffer, Bendtsen, \& Ulloa, 1999), with preferential uptake of organic nitrogen; Balsfjord waters being more efficient in remineralization in upper water column in comparison to Ullsfjord.

Statistical analysis of the measured DOC and Chl $a$ concentrations in 2003 gave statistically not significant correlation coefficient, $R=0.53(P=0.0048)$. This suggests that contrary to POC and PON, which represented contribution to the new OM production, the DOC pool in the UML in June 2003 was originating from multiple sources: background DOC, external DOC carried-in by snow melting and from the atmosphere, together with insitu freshly produced DOC by phytoplankton community.

Folic acid (FA) is widely spread in seawater as it is produced there by some microorganisms. Up to now it is known that FA producers are green algae and cyanobacteria (Aaronson et al., 1977; Plavšić, Terzić, Ahel, \& van den Berg, 2002). FA could be regarded as biomarker for these phytoplankton species. Very low values of FA, less than $1 \mathrm{nM}$, have been found in the UML in 2001. Low UML values were the result of the depletion of FA in surface layer and/or absence of its production. Generally, depletion could be a result of UV decomposition and/or FA consumption by the present bacteria and phytoplankton and/or vertical export. Known FA consumers are both the bacteria and phytoplankton, like e.g. the diatom Phaeodactylum tricornutum (Plavšić, Lu, \& van den Berg, 1997). High concentrations of FA have been found in the aphotic layer in 2001, up to $9.2 \mathrm{nM}$. This is indication that vertical water masses mixing and sedimentation contributed to FA surface export to the deeper layers and supports theory on limited bacterial activity on dissolved organic matter pool in UML. FA represented less than $0.01 \%$ of the DOC pool but its appearance due its high reactivity could be used as indication of freshly produced dissolved organic matter.

The high FA concentrations, up to $31 \mathrm{nM}$, found in 2003 are an indication that FA was very freshly produced as it is known that FA represents highly (bio)reactive and very labile organic substance (Plavšić, Lu, \& van den Berg, 1997; Le Gall \& van den Berg, 1998). FA 
has been highly enriched in the UML in 2003, EF $=1.62$ (Table 2). FA is the only measured parameter that has been found in lower concentration in Station B1 in comparison to Station U1. This could lead to the conclusion about higher FA consumption in Balsfjord by phytoplankton and/or bacteria. Higher bacterial activity in Balsfjord is also supported with increased $\mathrm{C} / \mathrm{N}$ ratio at lower depths at Station $\mathrm{B} 1$ as a result of higher/faster $\mathrm{OM}$ remineralization.

The correlation between FA and DOC, POC or PON was not found. Despite the fact that the highest FA concentrations were found at the depths with Chl a maxima, the correlation between FA and phytoplankton standing crop $(C h l a)$ was not established. The significant correlation between Chl $a$ and FA was not found either in earlier studies (Plavšić, Terzić, Ahel, \& van den Berg, 2002). Good correlations were established for the concentration of FA and zeaxanthin (biomarker for cyanobacteria) as well as for chl $b$ (biomarker pigment for green algae) in the investigated area of the Adriatic Sea (Plavšić et al. 2002). Cyanobacteria can be present in north Norwegian waters in late spring and summer. The spring succession of cyanobacteria Synechococcus sp. has been observed before main diatom bloom in Norwegian coastal waters (Larsen, Fonnes Flaten, Sandaa, Castberg, et al., 2004). Green algae are normally absent in the investigated fjords (T. Ratkova, pers. comm.). It can be assumed that some other phytoplankton species not investigated up to now as well could contribute to the production of FA in these fjords.

The concentrations of SAS differ between the UML and deep layers (Fig. 4). SAS in the bottom layer were in the range from $0.038-0.075 \mathrm{mg}^{-1}$ in equiv. of T-X-100. Estimated average SA values for Stations B101, B103 and U103 were $0.055,0.056$ and $0.055 \mathrm{mg} \mathrm{1}^{-1}$, respectively. So, the value of $0.055 \mathrm{mg} \mathrm{l}^{-1}$ in equiv. of T-X-100 can be considered as background value of SA for the North Norwegian fjords in late spring/summer period. SAS were enriched in the UML up to 1.74 times in 2001 and up to 1.98 times in 2003 (Table 2). There was also difference between the two fjords: Balsfjord waters were enriched with SAS in comparison to Ullsfjord waters (B1/U1) 1.19 times in 2001 and 1.07 times in 2003. Those differences were more pronounced in the upper $10 \mathrm{~m}$ layer, implying that nutrient input by freshwaters promoted additional phytoplankton activity and release of new SAS. For the upper 10 m layer SAS enrichment at Station B1 compared to Station U1 was 1.22 times in both years. Correlation between surfactant activity and salinity of the brackish water, as an indication of new nutrients and increased phytoplankton production, gave statistically significant correlation coefficient of $R=-0.76(P=0.0003)$. This inverse correlation suggests 
that fjords are likely an important source of OM to continental shelf ecosystem. Along with POC and PON, particulate SAS were found in the UML and at the surface of deep aphotic layer in 2001 (Fig. 4) and were completely depleted in deep waters. Particulate SAS are connected with the new production. The detected concentrations of SAS in the UML for this period of the year are comparable to warmer and eutrophic seas, such as Northern Adriatic (Gašparović and Ćosović 2001, 2003), although DOC pool in fjords was found to be lower compared to Northern Adriatic (Vojvodić \& Ćosović, 1996).

The highest variations of SA obtained in the UML strongly suggested that the SA of present OM originated mostly from phytoplankton community production. Indeed, statistical analysis of 15 data pairs of total SAS concentration and Chl a, measured in 2003, gave statistically significant correlation coefficient, $R=0.82(P=0.0003)$. From the equation of linear regression the following was obtained:

\section{$\mathrm{SA}\left(\mathrm{mg} \mathrm{l}^{-1}\right.$ equiv. to T-X-100) $=0.0162 \mathrm{Chl} a\left(\mu \mathrm{g} \mathrm{l^{-1 }}\right)+0.087$}

This means that SA values larger than $0.087 \mathrm{mg} \mathrm{l}^{-1}$ equiv. to $\mathrm{T}-\mathrm{X}-100$ represent fjords new SAS production that is the driving process of the carbon cycle in these fjords. As it is supposed that $0.055 \mathrm{mg} \mathrm{l}^{-1}$ represents background SA value for this region and season, the difference of $0.032 \mathrm{mg}^{-1}$ represent surface active organic substances which might originate from external sources, or SAS from lysed/or grazed phytoplankton cells. Recently, there is evidence for a new contribution to SAS in marine environment by protozoan grazers (Kujawinski et al. 2002).

Furthermore, inverse relation between SA and OM acidity in the UML ( $0-40 \mathrm{~m}$ depth) was determined: for increased SA decreased OM acidity is detected. As biogenic substances have lower relative acidity than more refractory humic material, this relation suggests that in the surface layer increased SA originate from freshly produced biogenic OM of phytoplanktonic origin (Gašparović \& Ćosović, 2003).

Concentrations of SAS in deep waters were dependant on sedimentation, bottom-up mixing and recycling of SAS from surface waters. Humic substances constitute a highly important portion of DOM in Norwegian coastal waters (Öztürk, Steinnes, \& Sakshaug, 2002). High SAS relative acidity, $\sim 191 \mathrm{mg}^{-1}$, has been detected in 2001 in deep waters of both fjords, indicating domination of highly acidic humic-type substances. Surface-active OM in deeper layers in 2003 had low relative acidity. This may be indication that biogenically produced and accumulated surface active OM of lower acidity in surface layer, such as 
polysaccharides, were transported in 2003 to the deeper waters in a relatively short period. The importance of polysaccharides in formation of POC and its sedimentation during phytoplankton bloom was observed by Engel et al. (2004). Børsheim, Myklestad, \& Sneli (1999) found that adsorbable carbohydrates were accumulated during the productive season in summer in the UML and represented significant constituents of OM in the entire depth profile in Trondheim fjord.

To better characterize complex mixture of $\mathrm{OM}$ in the fjord waters SA of filtered samples was normalized to DOC content. As presented in Fig. 5, OM exhibited adsorption characteristics close to polysaccharide xanthan. This was more pronounced for OM from the samples taken in June 2003. SAS present in the fjords differ between the two years. Linear fit of data from 2001 and 2003 showed that 0.63 and $0.60 \mathrm{mg} \mathrm{l}^{-1}$ of OM present, respectively, did not have surface-active properties and were not detectable by the electrochemical technique applied.

\section{Conclusions}

Subarctic North Norwegian fjord waters are characterized by distinct vertical, seasonal and horizontal OM variations. Their waters can be vertically divided in two layers: the upper mixed (UML), until $40 \mathrm{~m}$ depth, and deeper layer.

The samples taken in July were characterized with OM being of refractory nature with significant contribution of dissolved OM from the UML to deep layer. Increased concentrations of folic acid were found below UHL depth.

The UML waters in June represent the layer of pronounced phytoplankton originated new OM production. The new production is clearly detected by increased concentrations of POC, PON, SAS; up to $0.773 \mathrm{mg} \mathrm{C} 1^{-1}, 0.117 \mathrm{mg} \mathrm{N}^{-1}$ and $0.15 \mathrm{mg} \mathrm{l}^{-1}$ in equiv. of T-X-100, respectively. During very new phytoplankton production there was an increase of FA in the UML, up to $31 \mathrm{nmol}^{-1}$ on the $2^{\text {nd }}$ of June 2003 in Ullsfjord, Station U103. Deep waters in June were mostly depleted with POC, PON, SAS and FA. 
DOC pool represents a major component of organic carbon pool, amounting $65-87 \%$ in the UML, and $83-94 \%$ in deep fjord waters. In general, DOC pool is more refractory and originates from multiple sources: background DOC, external DOC carried-in by fresh waters and from the atmosphere, along with in-situ freshly produced DOC.

Due to the lower sill depth, there is lower influence of shelf waters and thus longer residence time of Balsfjord waters in comparison to Ullsfjord. This is manifested in increased phytoplankton standing crop, increased OM pool and more efficient OM remineralization in Balsfjord.

SAS in the UML mainly originates from phytoplankton new production. This is revealed in significant correlations between SAS concentration and decreased salinity that indicates nutrient inputs and promote phytoplankton activity, as well as those between SA and Chl $a$ concentration in the UML. SAS in the UML are found in the concentrations that are comparable to warmer eutrophic seas such as Northern Adriatic. The concentration of SAS obtained for the deeper layers that were $\sim 0.055 \mathrm{mg} \mathrm{l}^{-1}$ equiv. to T-X-100, can be considered as the background value for the North Norwegian fjords for the period of late spring/early summer.

The observed distinct $\mathrm{OM}$ distribution in investigated fjords indicates the potential importance of the results of this study in carbon cycling of subarctic waters.

\section{Acknowledgements}

Financial support of the Croatian Ministry of Science, Education and Sport, and the Norwegian Research Council, CPSEE program, project no. 149583/730 are gratefully acknowledged. Special thanks go to the project leader Dr. Paul Wassmann for general support during the project and to the crew of the research vessel "Hyas" for efficient technical assistance during the fieldwork. Our thanks are also extended to Mr. Zdeslav Zovko and Mr. Nikola Bošković for in-field sampling and DOC measurements. 


\section{References}

Aaronson, S., Dhawale, S.W., Patni, N.J., Deangelis, B., Frank, O. \& Baker, H. (1977). The cell content and secretion of water- soluble vitamins by several freshwater algae, Archives of Microbiology 112, 57-59.

Amon, R.M.W., Budéus, G. \& Meon, B. (2003). Dissolved organic carbon distribution and origin in the Nordic Seas: Exchanges with the Arctic Ocean and the North Atlantic. Journal of Geophysical Research 108, NO. C7, 3221.

Amon, R.M.W., Benner, R. (2003). Combined neutral sugars as indicators of the diagenetic state of dissolved organic matter in the Arctic Ocean. Deep-Sea Research I 50, 151-169.

Angel, A., Thoms, S., Riebessel, U., Rochelle-Newall, E., \& Zondervan, I. (2004). Polysaccharide aggregation as a potential sink of marine dissolved organic carbon. Nature 428, 929-932.

Børsheim, K.Y., \& Myklestad, S. M. (1997). Dynamics of DOC, in the Norwegian sea inferred from monthly profiles collected during 3 years at $66^{\circ} \mathrm{N}, 2^{\circ} \mathrm{E}$. Deep Sea Research $I$ 44, 593-601.

Børsheim, K.Y., Myklestad, S. M., \& Sneli, J-A. (1999). Monthly profiles of DOC, monoand polysaccharides at two locations in the Trondheimsfjord (Norway) during two years. Marine Chemistry 63, 255-272.

Cho, B.C., \& Azam, F. (1988). Major role of bacteria in biogeochemical fluxes in the ocean`s interior. Nature 332, 441-443.

Denant, V., Saliot, A., \& Mantoura, R.F.C. (1991). Distribution of algal chlorophyll and carotenoid pigments in a stratified estuary: the Krka River, adriatic Sea. Marine Chemistry 32, 285-297.

Ducklow, H.W., Carlson, C.A., Bates, N.R., Knap, A.H., \& Michaels, A.F. (1995). Dissolved organic carbon as a component of the biological pump in the North Atlantic ocean. Philosophical Transactions of the Royal Society of London 338, 161-167.

Eilertsen, H.C., Falk-Petersen, S., \& Hopkins, C.C.E. (1981). Ecological investigation on the plankton community of Balsfjorden, northern Norway: Program for the project, study area, topography and physical environment Sarsia 66, 25-34. 
Eilertsen, H.C., \& Taasen, J.P. (1984). Investigations on the plankton community of Balsfjorden, northern Norway: The phytoplankton 1976-1978. Environmental factors, dynamics of growth, and primary production. Sarsia 69, 1-15.

Gašparović, B. \& Ćosović, B. (1994). Electrochemical estimation of the dominant type of surface active substances in seawater samples using o-nitrophenol as a probe. Marine Chemistry 46, 179-188.

Gašparović, B. \& Ćosović, B. (1995). Electrochemical reduction of o-nitrophenol as a tool for the rough characterization of organic matter in seawater samples. Electroanalysis 7, 11361142.

Gašparović, B. \& Ćosović. B. 2001 Distribution of surface active substances in the North Adriatic Sea. Marine Chemistry 75, 301-313.

Gašparović, B. \& Ćosović. B., (2003). Surface-active properties of organic matter in the North Adriatic Sea. Estuarine Coastal and Shelf Science 58, 555-566.

Gašparović, B., Ćosović, B., \& Vojvodić, V. (1998). Contribution of organic acids to the pool of surface active substances in model and marine samples using o-nitrophenol as an electrochemical probe. Organic Geochemistry 29, 1025-1032.

Gilmartin, M., \& Revelante, N. (1991). Observations on particulate organic carbon and nitrogen concentrations in the northern Adriatic Sea. Thalassia Jugoslavica 23, 39-49.

Gobler, C.J., \& Sanudo-Wilhelmy, S. A. (2003). Cycling of colloidal organic carbon during an estuarine phytoplankton bloom. Limnology and Oceanography 48, 2314-2320.

Holm-Hansen, O. \& Riemann, B. (1978). Chlorophyll a determination: improvement in methodology. Oikos 30, 438-447.

Kujawinski, E. B., Farrington, J. W. \& Moffett, J. W. (2002). Evidence for grating-mediated production of dissolved surface-active material by marine protist. Marine Chemistry 77, $133-142$.

Larsen, A., Fonnes Flaten, G. A., Sandaa, R-A., Castberg, T., Thyrhaug, R., Rune Erga, S., Jacquet, S., \& Bratbak, G. (2004). Spring Phytoplankton bloom dynamics in Norwegian coastal waters: Microbial community succession and diversity. Limnology and Oceanography 49, 180-190. 
Le Gall, A.C., \& van den Berg, C.M.G. (1993). Determination of folic acid in seawater using adsorptive cathodic stripping voltammetry. Analitica Chimica Acta 282, 459-470.

Le Gall, A.C., \& van den Berg, C.M.G. (1998). Folic acid and glutathione in the water column of the North East Atlantic. Deep-sea research I 45, 1903-1918.

Middelboe, M., \& Lundsgaard, C. (2003). Microbial activity in the Greenland Sea: role of DOC lability, mineral nutrients and temperature. Aquatic Microbial Ecology 32, 151-163.

Münster, U. (1993). Concentrations and fluxes of organic carbon substrates in aquatic environment. Antonie van Leeuwenhoek 63, 243-274.

Öztürk, M., Steinnes, E., \& Sakshaug, E. (2002). Iron Speciation in the Trondheim Fjord from the Perspective of Iron Limitation for Phytoplankton, Estuarine Coastal and Shelf Science $55,197-212$.

Pantoja, S., Sepúlveda, J., \& González, H. E. (2004). Decomposition of sinking proteinaceous material during fall in the oxygen minimum zone of northern Chile. Deep-Sea Research I. $51,55-70$.

Plavšić, M. (2004). Long term investigations of folic acid concentrations in the Northern Adriatic. Environment International 30, 761-767.

Plavšić, M., Lu, X., \& van den Berg, C.M.G. (1997). A voltammetric study of the reactivity of folic acid in algal cultures and in natural waters. Croatica Chemica Acta 70, 179-91.

Plavšić, M., Terzić, S., Ahel, M., \& van den Berg, C.M.G. (2002). Folic acid in coastal waters of the Adriatic Sea. Marine and Freshwater Research 53, 1245-1252.

Pomeroy, L.R., \& Deibel, D. (1986). Temperature regulation of bacterial activity during the spring bloom in Newfoundland coastal waters. Science 233, 359-361.

Reigstad, M., Wassmann, P., Ratkova, T., Arashkevich, E., Pasternak, A., \& Oygarden S. (2000). Comparison of the springtime vertical export of biogenic matter in three northern Norwegian fjords. Marine Ecology Progress Series 201, 73-89.

Riebesell, U., Reigstadt, M., Wassmann, P., Noji, T., \& Passow, U. (1995). On the trophic fate of Phaeocistys pouchetii (Hariot): VI. Significance of phaeocystis-derived mucus for vertical flux. Netherland Journal of Sea Research 33, 193-203.

Rudels, B., \& Quadfasel, D. (1991). Convection and deepwater formation in the Arctic Ocean-Greenlanf Sea system. Journal of Marine Systems 2, 435-450. 
Schlesinger, W.H. (1997). Biogeochemistry: An Analysis of Global Change (588 pp.). New York: Academic Press.

Shaffer, G., Bendtsen, J., \& Ulloa, O. (1999). Fractionation during remineralization of organic matter in the ocean. Deep-Sea Research I 46, 185-204.

Sugimura, Y., \& Suzuki, Y. (1988). A high-temperature catalytic method for the determination of non-volatile dissolved organic carbon in seawater by direct injection of a liquid sample. Marine Chemistry 24, 105-131.

Thurman, E.M., (1985). Organic chemistry in natural waters (489 pp.). Junk: Dordrecht.

Vernet, M., Matrai, P. A. \& Andreassen, I. J. (1998). Synthesis of particulate and extracellular carbon by phytoplankton at the marginal ice-zone in the Barents Sea. Journal of Geophysical Research-Oceans 103, 1023-1037.

Vojvodić, V., \& Ćosović, B. (1996). Fractionation of surface active substances on XAD-8 resin: Adriatic Sea samples and phytoplankton culture media. Marine Chemistry 54, 119 133.

Wassmann, P. (1998). Retention versus export food chains: processes controlling sinking loss from marine pelagic systems. Hydrobiologia 363, 29-57.

Wassmann, P., Svensen, H., Keck, A., \& Reigstadt, M. (1996). Selected aspects of the physical oceanography and particulate fluxes in fjords of northern Norway, Journal of Marine Systems 8, 53-71.

Wassmann, P., Olli, K., Wexels Riser, C., \& Svensen, C. (2003). Ecosystem function, biodiversity and vertical flux regulation in the twilight zone. In G. Wefer, F. Lamy \& F. Mantoura (Eds.), Marine Science Frontiers for Europe (pp. 277-285). Berlin: Springer.

Williams, P. M., \& Druffel, R. M. (1987). Radiocarbon in dissolved organic matter in the central North Pacific Ocean. Nature 330, 246-248.

Wollast, R. (1991). The coastal organic carbon cycle: fluxes, sources and sinks. In R.F.C. Mantoura, J.-M. Martin, \& Wollast, R. (Eds.) Ocean margin Processes in Global Change, Dahlem Workshop Reports. (pp. 365-381). Chichester: Wiley.

Žutić, V., Ćosović, B., Marčenko, E., Bihari, N., \& Kršinić, F. (1981). Surfactant production by marine phytoplankton. Marine Chemistry 10, 505-520. 


\section{Figure captions:}

Fig. 1. Sampling stations in the investigated area of North Norwegian fjords

Fig. 2. (A) Vertical profiles of temperature ( $\square$ ) and salinity $(\Delta)$ variations, (B) depth variations of Chl $a$ (o). Results are presented for the Balsfjord (Stations B1 and B2) and Ullsfjord (Station U1) in 2001 (01) and in 2003 (03).

Fig. 3. Distribution of folic acid (FA) (nmol 1-1) along the depth profile for (A) 2001 and (B) 2003 for B101- $\Delta, \mathrm{B} 103-\nabla, \mathrm{B} 203-\circ, \mathrm{U} 101-\diamond, \mathrm{U} 103-\square$.

Fig. 4. (A) Surfactant activity (SA), (in equiv. of T-X-100 $\left.\left(\mathrm{mg} \mathrm{l}^{-1}\right)\right)(\Delta)$, (B) distribution of relative acidity $\left(1 \mathrm{mg}^{-1}\right)$ of SAS $(\nabla)$, and $(C)$ percentage contribution of particulate SAS to the total SAS $(\diamond)$.

Fig. 5. Correlation of SAS concentrations (in equiv. of T-X-100, $\mathrm{mg}^{-1}$ ) in filtered samples and DOC values of the same samples: 2001 (open marks) and 2003 (closed marks). Lines inserted are SAS-DOC correlations for the indicated selected model substances: fulvic acid, protein albumin and high molecuar acidic polysaccharide xanthan 
Gašparović et al.

Fig. 1.

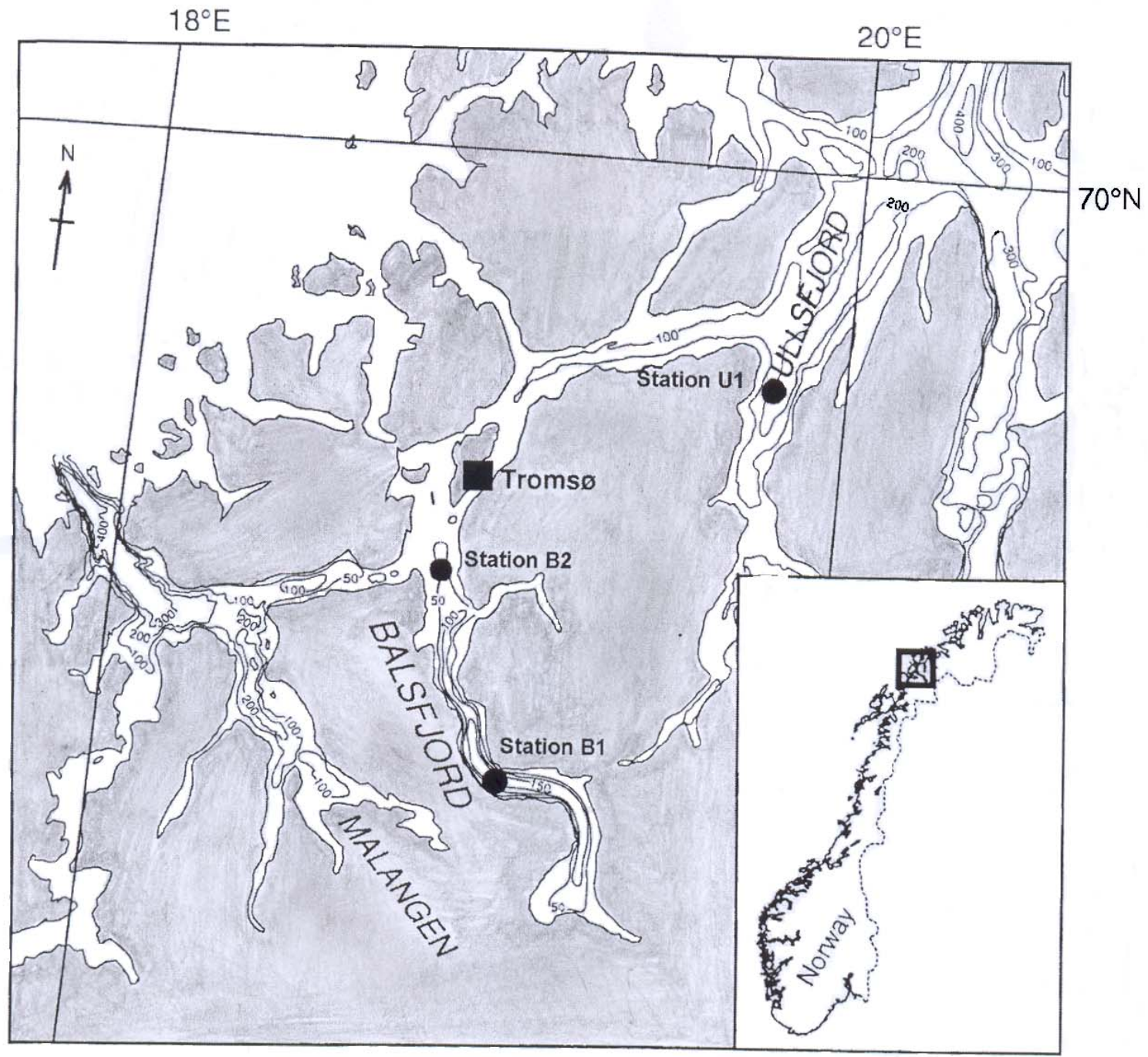


Gašparović et al.

Fig. 2.
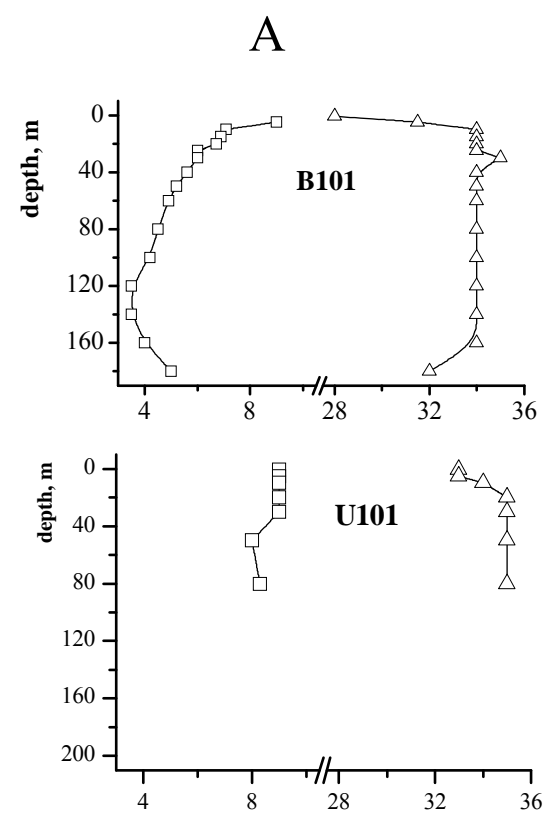

B
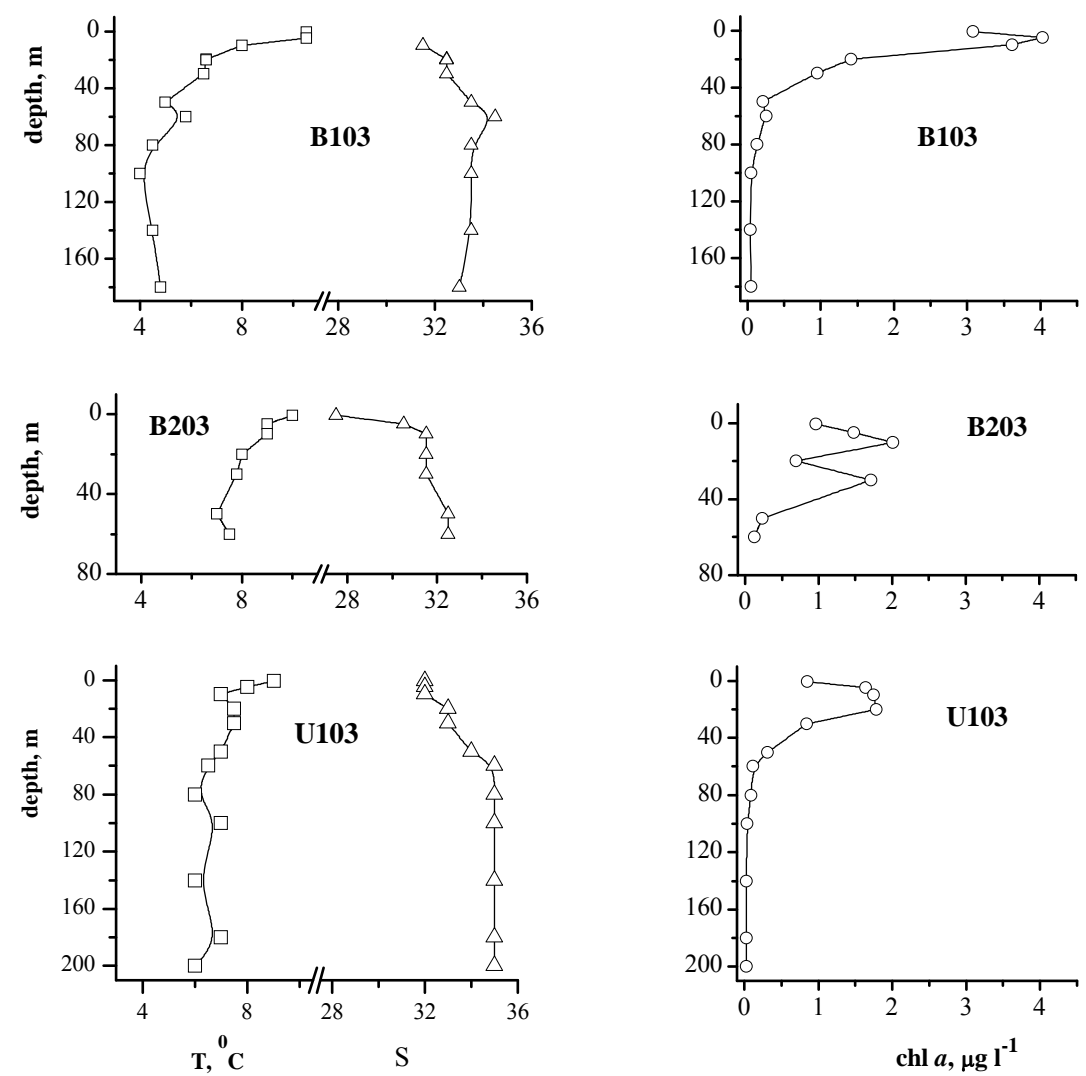
Gašparović et al.

Fig. 3.

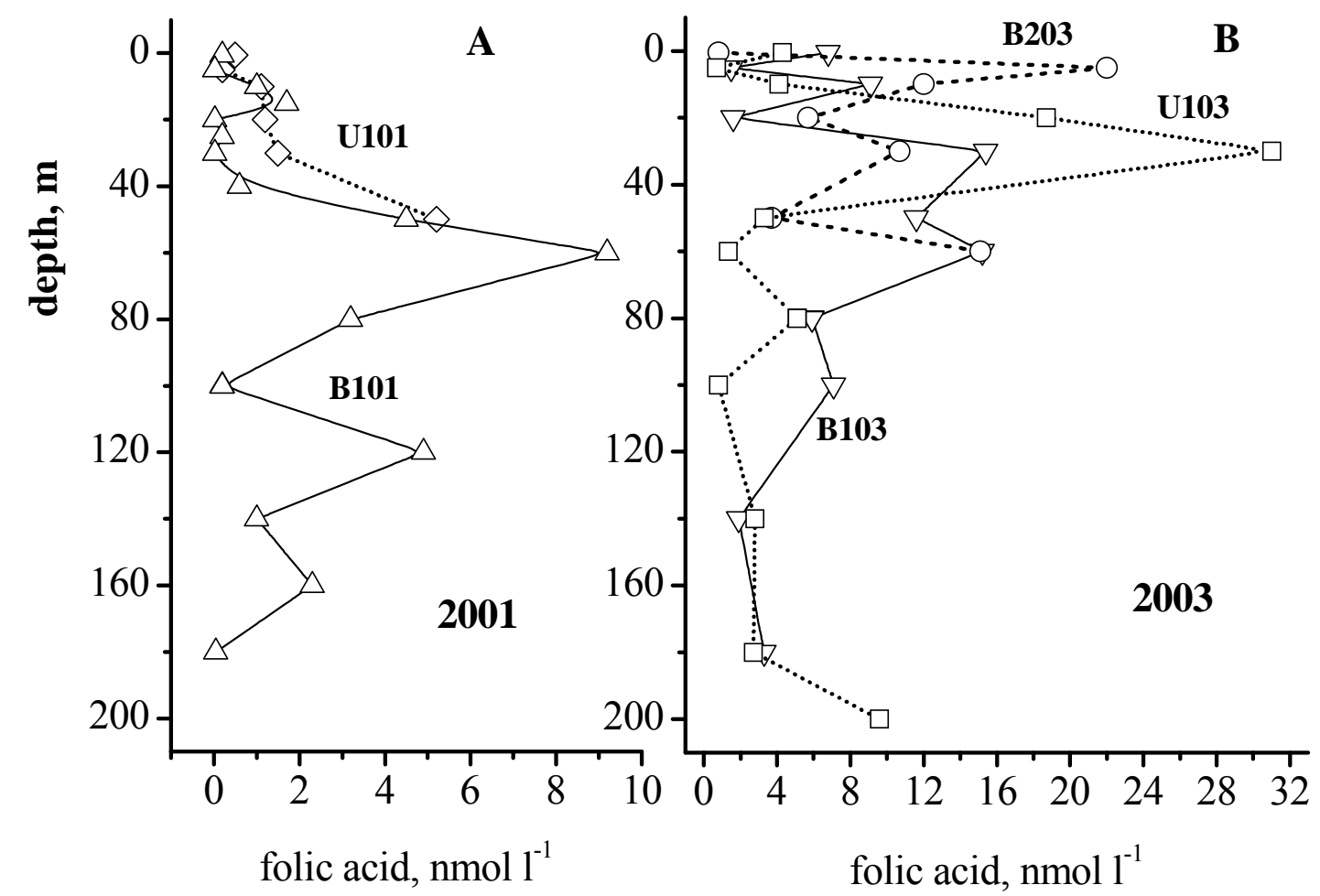


Gašparović et al.

Fig. 4.

A
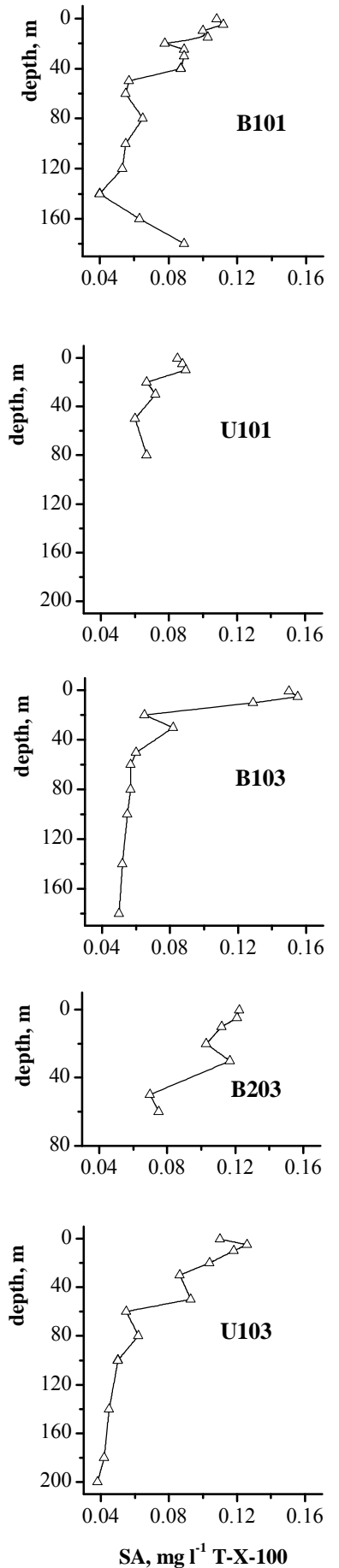

B
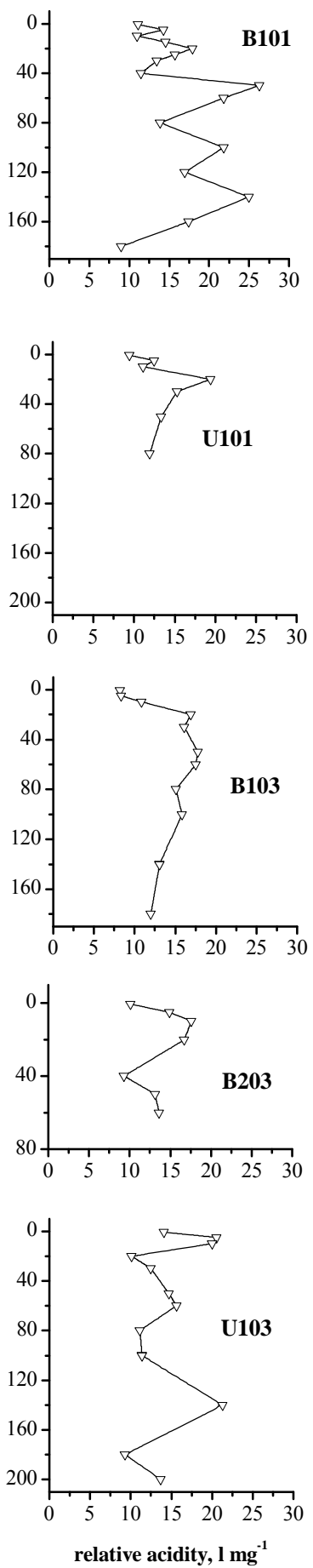

C
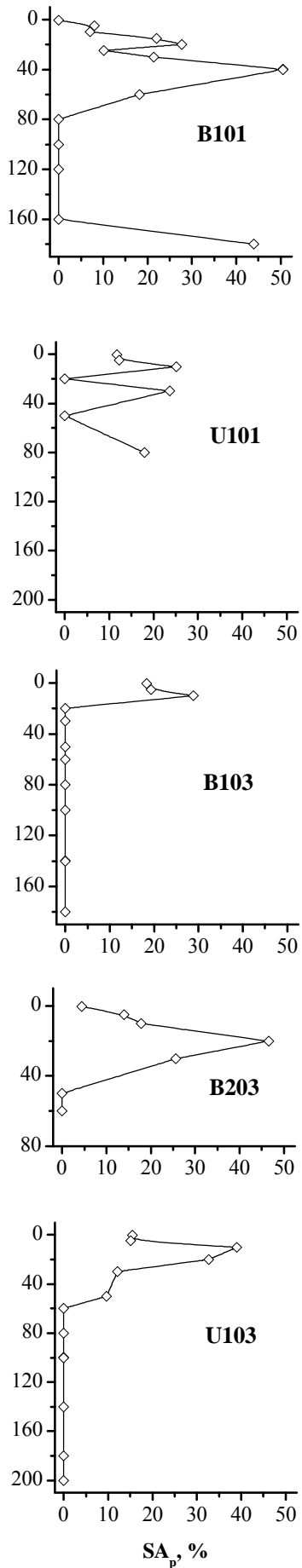
Gašparović et al.

Fig. 5.

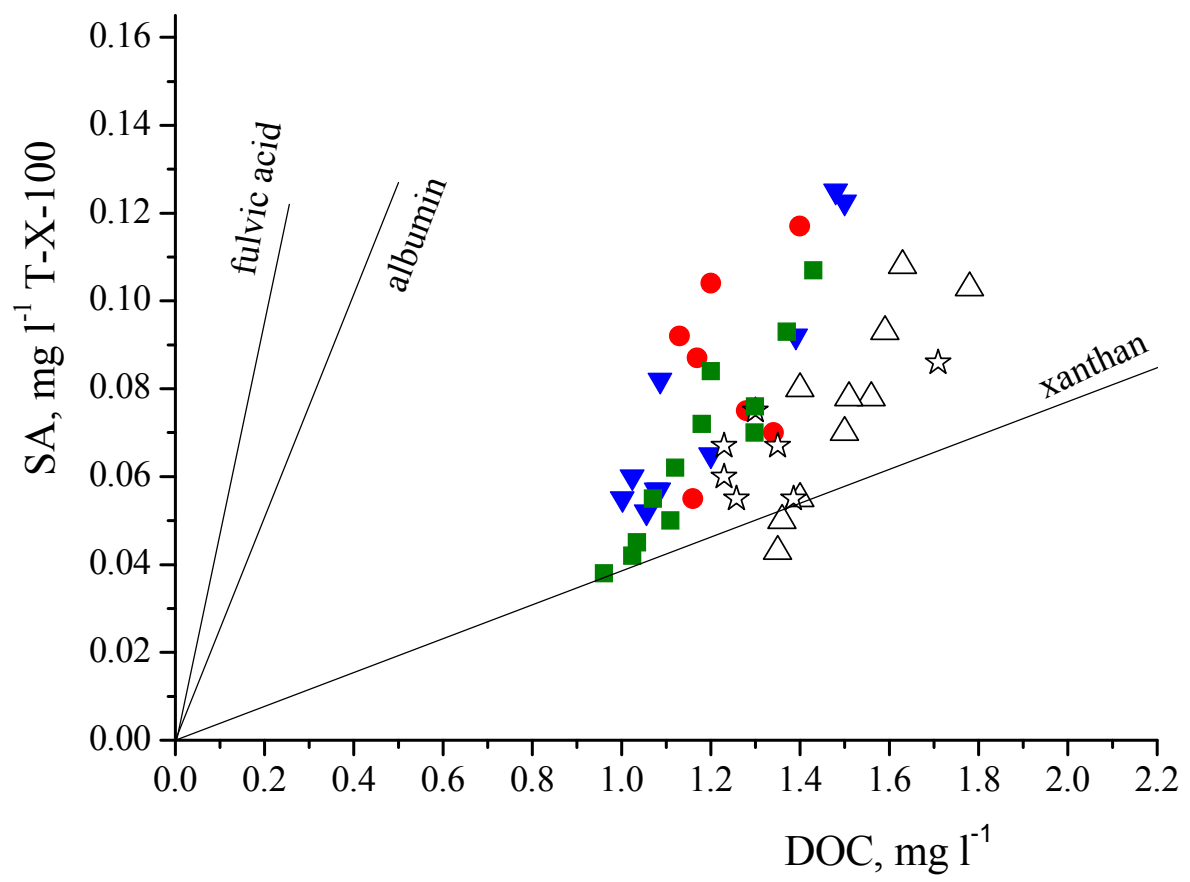

